\title{
RESEARCHING MEANING, CONTEXT AND COGNITION EDITORIAL TO RIL SPECIAL ISSUE
}

\author{
IWONA WITCZAK-PLISIECKa \\ University of Łódź \\ wipiw@uni.lodz.pl
}

The present issue of Research in Language has been inspired by discussions conducted during the meetings of the annual international conference "Meaning, Context \& Cognition" (MCC), held in University of Łódź, Poland, since 2011. MCC, organised by the Department of English Language and Applied Linguistics, focuses on topics relevant to the fields of speech actions and natural language processing. The goal of the conference has been to integrate and promote both theoretical and applied research from the interface of semantics and pragmatics.

The papers included in the volume, even though few in number, reflect the wide range of interests represented by MCC participants and complement other collections inspired by MCC meetings (cf. Witczak-Plisiecka 2013). They are diverse in the choice of particular research programmes, but well integrated by the authors' interest in the processes hidden behind linguistic action. The papers explore how meaning arises in particular contexts, and how language studies intersect with other fields of human action. Among the languages discussed in the articles there are: Basque, Czech, French, English, Polish, Arabic, Mandarin Chinese, and Italian. The cognitive-pragmatic research frameworks include, inter alia, relevance theory, Langacker's cognitive grammar, critical pragmatics, and conversation analysis.

The first paper "(Non-)Determining the original speaker: reportative particles versus verbs", by Larraitz Zubeldia, focuses on the Basque reportative particle omen. The discussion is based on Korta and Perry's (2007, 2011) conception of propositional content, on the basis of which the author claims that the presence of "omen" contributes to the propositional content of the utterance. The author also explicitly subscribes to relevance theoretic framework (Sperber and Wilson 1986/1995). With data obtained from an assent/dissent test and a controlled experiment, it is argued, against the received view, that the function of both "omen" and a relater verb, "esan" ("to say"), goes beyond that of an illocutionary force indicator and that there is a theoretically important difference between the meaning of omen-sentences and the contents of omen-utterances. The nature of "omen", as well as its relation to "esan", is discussed with reference to varied methodological tools, not only experiments, but also native speakers' intuitions and corpora. The paper is also a contribution in the field of research focused on evidentiality, respecting Wilson's proposal (2011) to distinguish between lexicalized and grammaticalised evidentials and epistemic modals. It reports facts from the Basque language and poses Basque-related questions. 
The theme of evidentiality is further explored by Milada Hirschová in "Sentence adverbials and evidentiality", a paper discussing expressions of evidence (originating in perception, inference or reported information) and their role in sentence/utterance pragmatic modification. The paper focuses on the role of the so-called sentence adverbials, citing numerous examples from Czech and providing a thorough description of their varied forms and functions. It is claimed that in languages not expressing evidence as a grameme, the embodiment of the evidentiality-related element can occur in almost any sentence position. Expressing evidences overlap with pragmatic modifications, or with expressing communicative strategies like reasoning or explanation, in other words, with the so-called subsidiary illocutions, which are entirely pragmatic. In languages like Czech, evidentiality is shown to fall into the semantic/pragmatic domain, merging with other, i.e. non-evidential, pragmatic modifications of a sentence/utterance.

"Discourse-driven meaning construction in neosemantic noun-to-verb conversions" is the topic of the next paper authored by Rafal Augustyn. Conversions of the type beer $\rightarrow$ to beer, door $\rightarrow$ to door, pink $\rightarrow$ to pink, are discussed within a cognitive linguistics approach as items which involve discourse-guided and context-based interpretation. Methodologically, the analysis draws on Fauconnier and Turner's (e.g. 2002) Conceptual Integration Theory and Langacker's (e.g. 2008) Current Discourse Space.

Federico Farini's paper entitled "The pragmatics of emotions in interlinguistic healthcare settings" is a data-based study of medical interactions which involve migrant patients. The focus is on the interpreters' role and proficiency in rendering emotionallyloaded concerns expressed by the patients in intercultural settings. The data under analysis includes 300 transcripts of interactions which took place in Italy, which are discussed within an intercultural pragmatic framework (e.g. Angelelli 2004) and the methodology of conversation analysis.

The last two papers are focused on political discourse. In "“Energy independence': President Obama's rhetoric of a success story", Stephanie Bonnefille explores the tropes used in President Obama's rhetoric on energy and environmental issues. Using corpus linguistics methodology, the author indicates how well known topics, such the Space Race, the Cold War, or 9/11, receive a new value by defining reasoning related to other issues. It is argued that the cognitive linguistic approach to rhetoric (e.g. Sperber (2007 [1975]), Gibbs (1994)) is able to elucidate conceptualisation mechanisms active in shaping the image of a consistent political position, and create a virtual success story.

Ewa Gieron-Czepczor's text, "Verbal warfare in the Polish media: An analysis of conceptual metaphors in political discourse", further explores political rhetoric in a cognitive linguistic approach, focusing on Polish data. In the author's opinion, Polish political discourse, in contrast to widely discussed discourses of, e.g. Obama and Bush, is primarily focused on Polish internal issues. As a result, the Polish political discourse mirrors the most visible feature of Polish politics, which is conflict. On the basis of corpus data, culled between September 2011 and mid-January 2012, the study traces conceptual metaphors used by Polish politicians and the metaphors that journalists use when narrating political events in Poland. The sources also include daily news published on popular portals and online services of selected Polish dailies and magazines. It is suggested that the analyses of spoken and written data reveals that political, social and economic antagonisms are propelled by language which highlights dichotomies and 
depicts "the others" as a source of evil. The metaphors of the Polish language are shown to be consistent with the patterns investigated and described by Anglo-American cognitive linguists (e.g. Lakoff 1987; Lakoff \& Johnson 1980), providing a wealth of material to support the claim that ARGUMENT IS WAR.

\section{Bibliography}

Angelelli, Claudia V. (2004). Medical Interpreting and Cross-cultural Communication. Cambridge: Cambridge University Press.

Fauconnier, Gilles \& Mark Turner (2002). The Way We Think. Conceptual Blending and the Mind's Hidden Complexities. New York: Basic Books.

Gibbs, Ray (1994). The Poetics of Mind. Figurative Thought, Language, and Understanding. Cambridge: Cambridge University Press.

Korta, Kepa \& John Perry (2007). "How to say things with words". In Savas L. Tsohatzidis (Ed.), John Searle's philosophy of language: force, meaning, and thought (169-189). Cambridge: Cambridge University Press.

Korta, Kepa \& John Perry (2011). Critical pragmatics: An inquiry into reference and communication. Cambridge: Cambridge University Press.

Lakoff, George (1987). Women, Fire, and Dangerous Things. What Categories Reveal about the Mind. Chicago and London: University of Chicago Press.

Lakoff, George \& Mark Johnson (1980). Metaphors We Live By. Chicago: University of Chicago Press. Langacker, Ronald W. (2008). Cognitive Grammar. A Basic Introduction. New York: Oxford University Press

Sperber, Dan (2007 [1975]). "Rudiments of cognitive rhetoric". Rhetoric Society Quaterly, vol. 37, Issue 4, 361-400.

Sperber, Dan \& Deirdre Wilson (1986/1995). Relevance. Communication \& cognition. Oxford: Blackwell.

Witczak-Plisiecka, Iwona (ed.) (2013) Cognitive and Pragmatic Aspects of Speech Actions. Frankfurt am Main: Peter Lang. 